\title{
Testing of a Portion of Site 41WN104 in Advance of Proposed Improvements to Jackson Nature Park, Stockdale, Wilson County,
}

\section{Texas}

Antonia L. Figueroa

Center for Archeological Research, University of Texas at San Antonio

Follow this and additional works at: https://scholarworks.sfasu.edu/ita

Part of the American Material Culture Commons, Archaeological Anthropology Commons, Environmental Studies Commons, Other American Studies Commons, Other Arts and Humanities Commons, Other History of Art, Architecture, and Archaeology Commons, and the United States History Commons

Tell us how this article helped you.

This Article is brought to you for free and open access by the Center for Regional Heritage Research at SFA ScholarWorks. It has been accepted for inclusion in Index of Texas Archaeology: Open Access Gray Literature from the Lone Star State by an authorized editor of SFA ScholarWorks. For more information, please contact cdsscholarworks@sfasu.edu. 
Testing of a Portion of Site 41WN104 in Advance of Proposed Improvements to Jackson Nature Park, Stockdale, Wilson County, Texas

\section{Creative Commons License}

(c) (1) (8)

This work is licensed under a Creative Commons Attribution-NonCommercial 4.0 International License 


\section{Testing of a Portion of Site 41WN104}

in Advance of Proposed Improvements to Jackson Nature Park, Stockdale, Wilson County, Texas

by

Antonia L. Figueroa

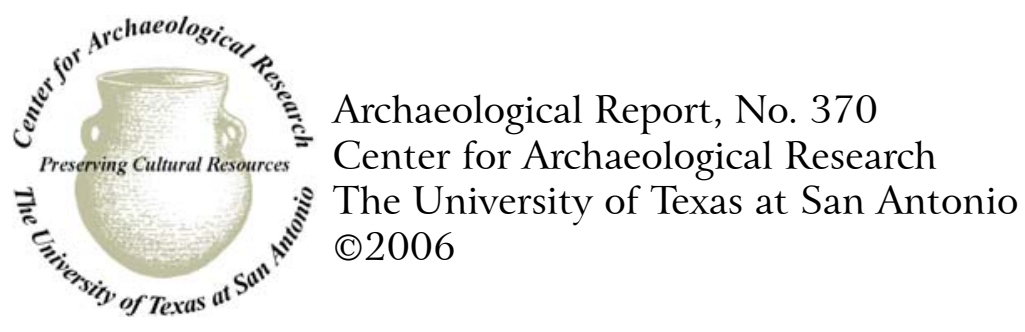




\section{Testing of a Portion of Site 4IWN104 in Advance of Proposed Improvements to Jackson Nature Park, Stockdale, Wilson County, Texas}

by

Antonia L. Figueroa

Jennifer L. Thompson

Principal Investigator

Texas Antiquities Permit No. 4189

prepared for

Office of the Wilson County Judge

Wilson County, Texas prepared by

Center for Archaeological Research The University of Texas at San Antonio Archaeological Report, No. 370 
On the cover: Aerial view of Jackson Nature Park and adjacent land, facing northeast.

A list of publications offered by the Center for Archaeological Research is available. Call (210) 458-4378; write to the Center for Archaeological Research, The University of Texas at San Antonio, One UTSA Circle, San Antonio, Texas 78249-1644; e-mail to car@utsa.edu; or visit CAR's web site at http://car.utsa.edu. 


\section{Abstract}

On July 25, 2006 the Center for Archaeological Research at The University of Texas at San Antonio conducted archaeological testing on portions of 41WN104 located in the Jackson Nature Park in Wilson County, Texas. The archaeological work, performed for the Office of the Wilson County Judge, was conducted on portions of 41WN104 that will be impacted by park improvements. The proposed improvements for the Jackson Nature Park will consist of the construction of a pavilion, a headquarters building and the addition of a septic tank. The three planned facilities will be connected with water and utilities lines. The construction of the two pads, the installation of the septic system, and the resulting utilities installations will result in subsurface impacts to the site. The testing was performed under Texas Antiquities Permit No. 4189 with Jennifer L. Thompson serving as the Principal Investigator and Antonia L. Figueroa serving as the Project Archaeologist.

Six shovel tests and one backhoe trench were excavated during the archaeological investigations of the site. Shovel test excavations revealed a scatter of burned rock and lithic debitage. Intact soils are present in the area of the two proposed building pads, with minimal disturbance in the pavilion area associated with vegetation clearance. Cultural material is present to at least one meter below surface in the business headquarters area. Shovel testing along the proposed utility route revealed disturbance associated with improvements to an existing two-track road. Though the backhoe trench excavations failed to encounter features or in situ material, three pieces of debitage were recovered from screening and the soil seemed to be undisturbed. No features were identified during the investigations although two projectile points were encountered in shovel tests that appear to be Late Archaic and Late Prehistoric forms, respectively.

While planned improvements to the Jackson Nature Park will impact portions of 41WN104, archaeological investigations in these areas failed to encounter intact features. Further work in these tested areas is not recommended. We recommend that the proposed improvements to the park proceed as planned. However, if construction plans change, including the route of the utilities, additional testing may be necessary.

All artifacts collected during this project as well as all project associated documentation are curated at the Center for Archaeological Research according to Texas Historical Commission guidelines. 


\section{Table of Contents}

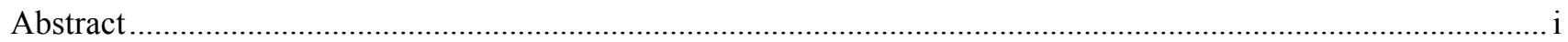

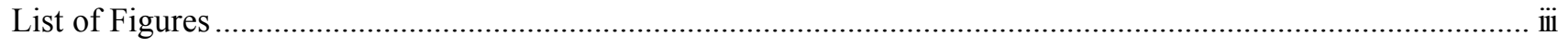

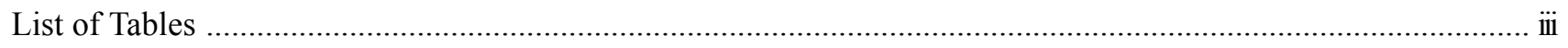

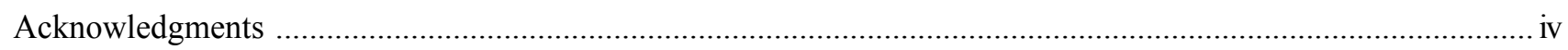

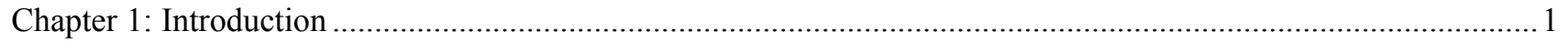

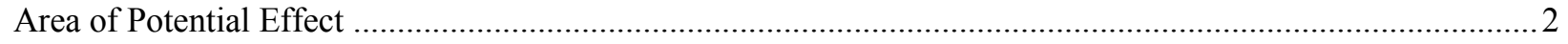

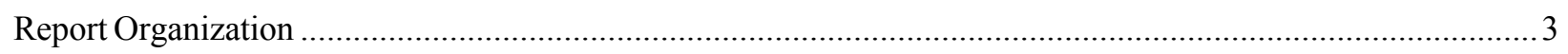

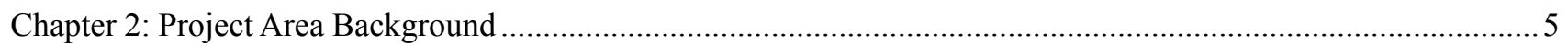

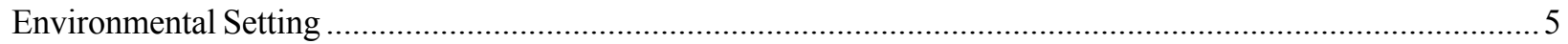

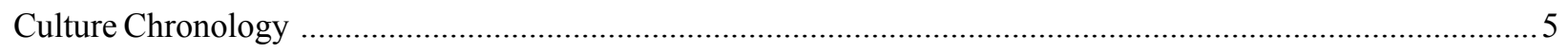

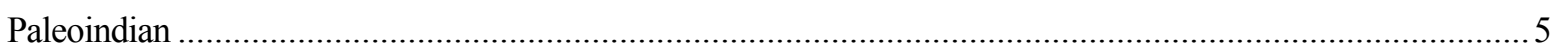

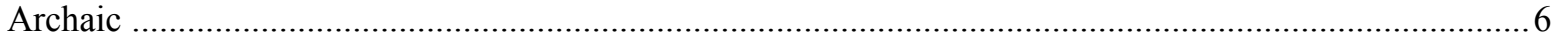

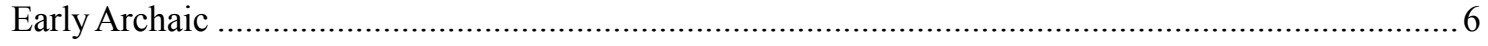

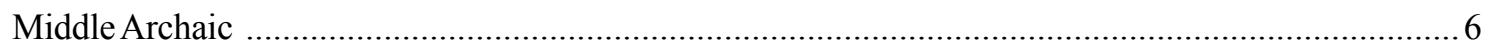

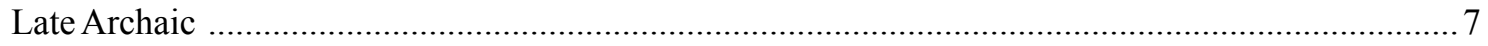

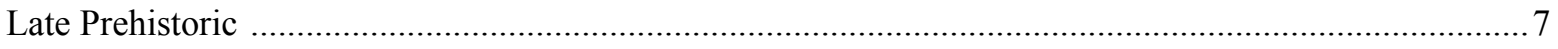

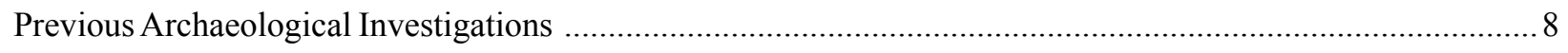

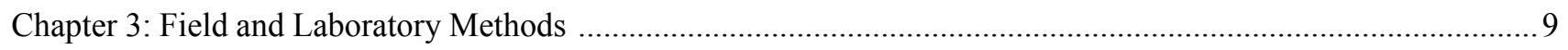

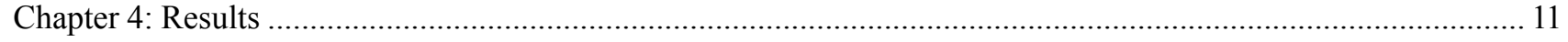

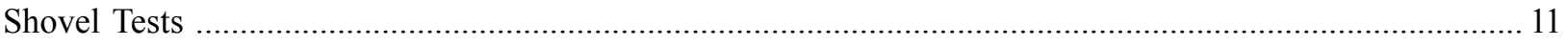

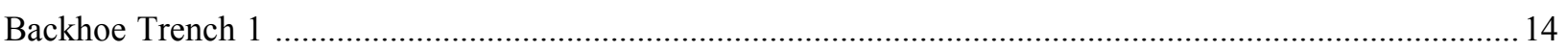

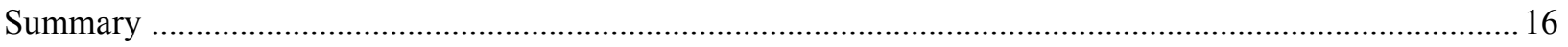

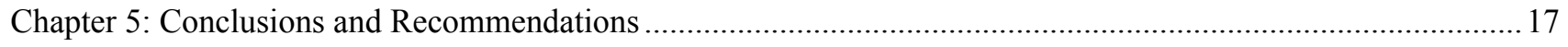

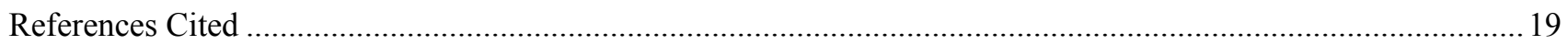




\section{List of Figures}

Figure 1-1. Location of Jackson Nature Park, Wilson County, Texas. …............................................................... 1

Figure 1-2. Location of planned improvements, shovel tests, and Backhoe Trench 1 .......................................2

Figure 4-1. Area of proposed business headquarters (facing south) .............................................................. 11

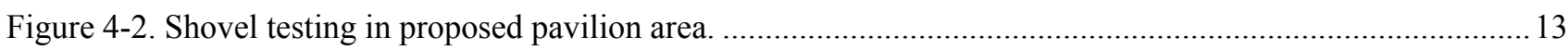

Figure 4-3. Projectile points recovered from 41WN104: (a) Late Archaic dart point; (b) Late Prehistoric

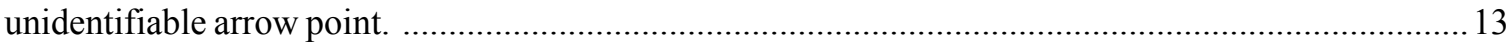

Figure 4-4. Shovel testing along proposed utility line between proposed business headquarters facility and septic tank 14

Figure 4-5. Proposed route of utility line running south from septic tank along two-track road. ......................... 15

Figure 4-6. Average burned rock and debitage recovered from shovel tests, per excavated level.......................... 15

Figure 4-7. Profile of a portion of the west wall of Backhoe Trench 1 ............................................................ 16

\section{List of Tables}

Table 4-1. Distribution of Artifacts by Shovel Test and Level 12 


\section{Acknowledgments}

Though there was only one day of fieldwork there were several individuals who aided in coordinating the project. The Center of Archaeological Research would like to thank Dale Branford of the San Antonio River Authority and Judge Marvin Quinney of the Office of the Wilson County Judge. Special thanks to James Jay of the Office of the Wilson County Judge for arranging the backhoe. The field crew consisted of Jason Perez, Jennifer Thompson, Joseph Thompson and Antonia Figueroa. The author would like to thank Jennifer Thompson and Dr. Steve Tomka for providing comments during the report production. The author would also like to thank Bruce Moses for drafting report figures. 


\section{Chapter 1: Introduction}

On July 25, 2006 the Center for Archaeological Research (CAR) at The University of Texas at San Antonio conducted archaeological testing within the confines of site 41WN104, located in the Jackson Nature Park near Stockdale, Wilson County, Texas (Figure 1-1). The archaeological work was conducted for the Office of the County Judge of Wilson County that has several planned improvements scheduled for Jackson Nature Park that will impact portions of $41 \mathrm{WN} 104$. The site was originally recorded by Marianne Marek in 2001 (Marek 2001). The State Archaeological Landmark (SAL) and National Register of Historic Places (NRHP) status of the site was undetermined during its initial recording in 2001. The Texas Historical Commission (THC) recommended that additional testing for significant cultural deposits be undertaken in advance of any developments within the park. The testing of selected portions of site
41WN104 was undertaken by the Center for Archaeological Research at the University of Texas at San Antonio in direct response to this THC request and occurred within the specific areas to be impacted by the proposed construction. The archaeological testing of $41 \mathrm{WN} 104$ was performed under Texas Antiquities Permit No. 4189, with Jennifer Thompson serving as the Principal Investigator and Antonia Figueroa serving as the Project Archaeologist. Archaeological testing of $41 \mathrm{WN} 104$ by CAR included the excavation of six shovel tests and one backhoe trench. Cultural material retrieved from excavations included firecracked rock (FCR), lithic debitage and two projectile points. Though both of the projectile points were too fragmented to be typed, the dart point appeared to be a Late Archaic form. The second projectile point, also broken and untypable, was identified as an arrow point.

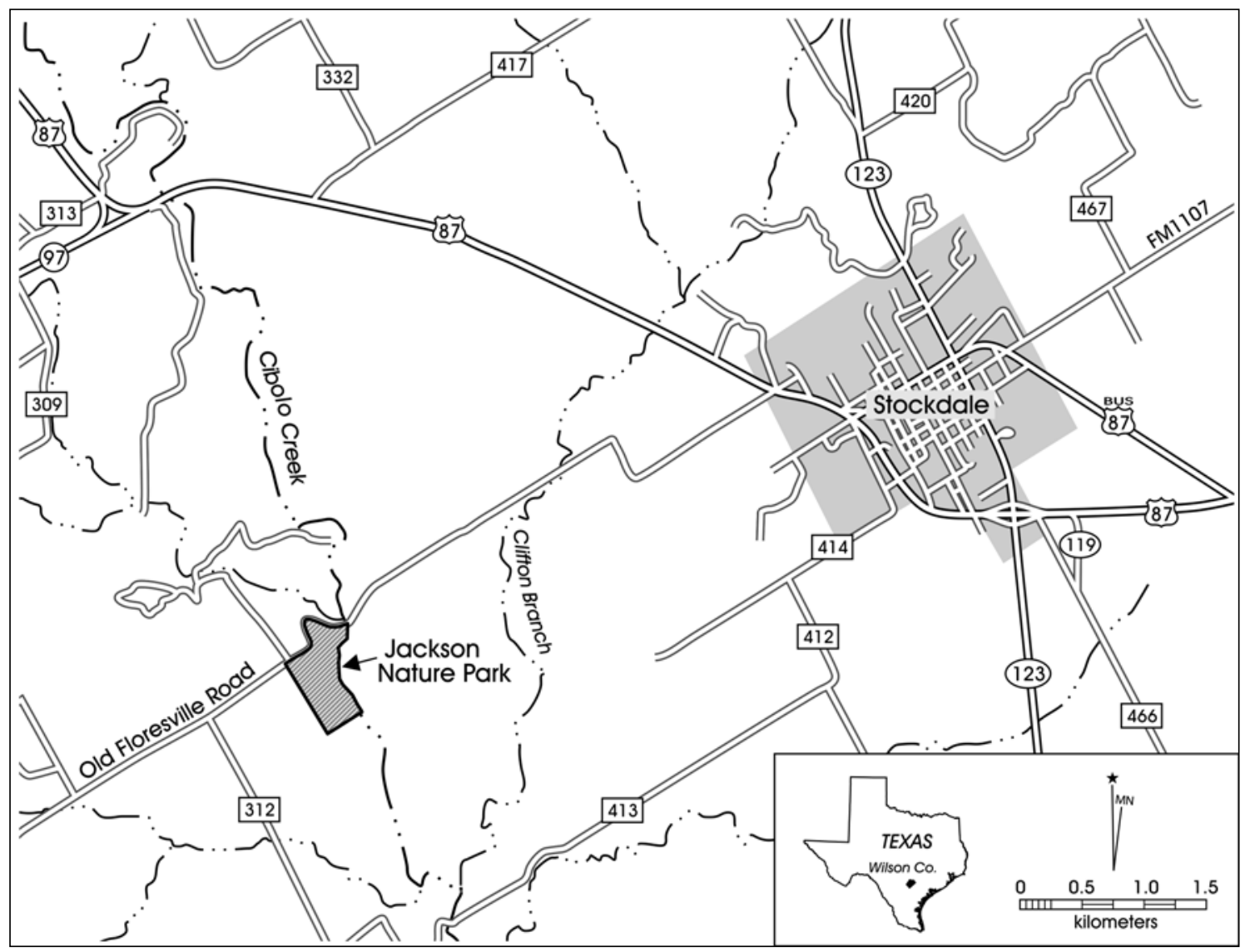

Figure 1-1. Location of Jackson Nature Park, Wilson County, Texas. 


\section{Area of Potential Effect}

The planned improvements that will be occurring in the Jackson Nature Park will impact three closely spaced areas within the park: (1) the $30-\mathrm{x}-60-\mathrm{ft}$. headquarters building pad; (2) the 30-x-40-ft. pavilion pad; and (3) a 10-x-10-ft. and 9 -ft. deep area excavated for the installation of the septic tank (Figure 1-2). The depth of the disturbances, associated with the pads, is not anticipated to exceed 6 in. In addition, the three facilities will be connected with utilities installed in a combined total of $200 \mathrm{ft}$. of trenching. The trenches will be 12 in. wide and 12 in. deep. The locations of the proposed utilities were altered the day of fieldwork, resulting in a reduction of the number of shovel tests (see Chapter 3). These improvements and subsurface disturbances represent the total Area of Potential Effect. Impacts to the site reported in 2001 included the installation of a fence along the western boundary of the park (Marek 2001). Impacts on the southern portion of the site that are located within two gravel quarries include the construction of an amphitheater and visitors center.

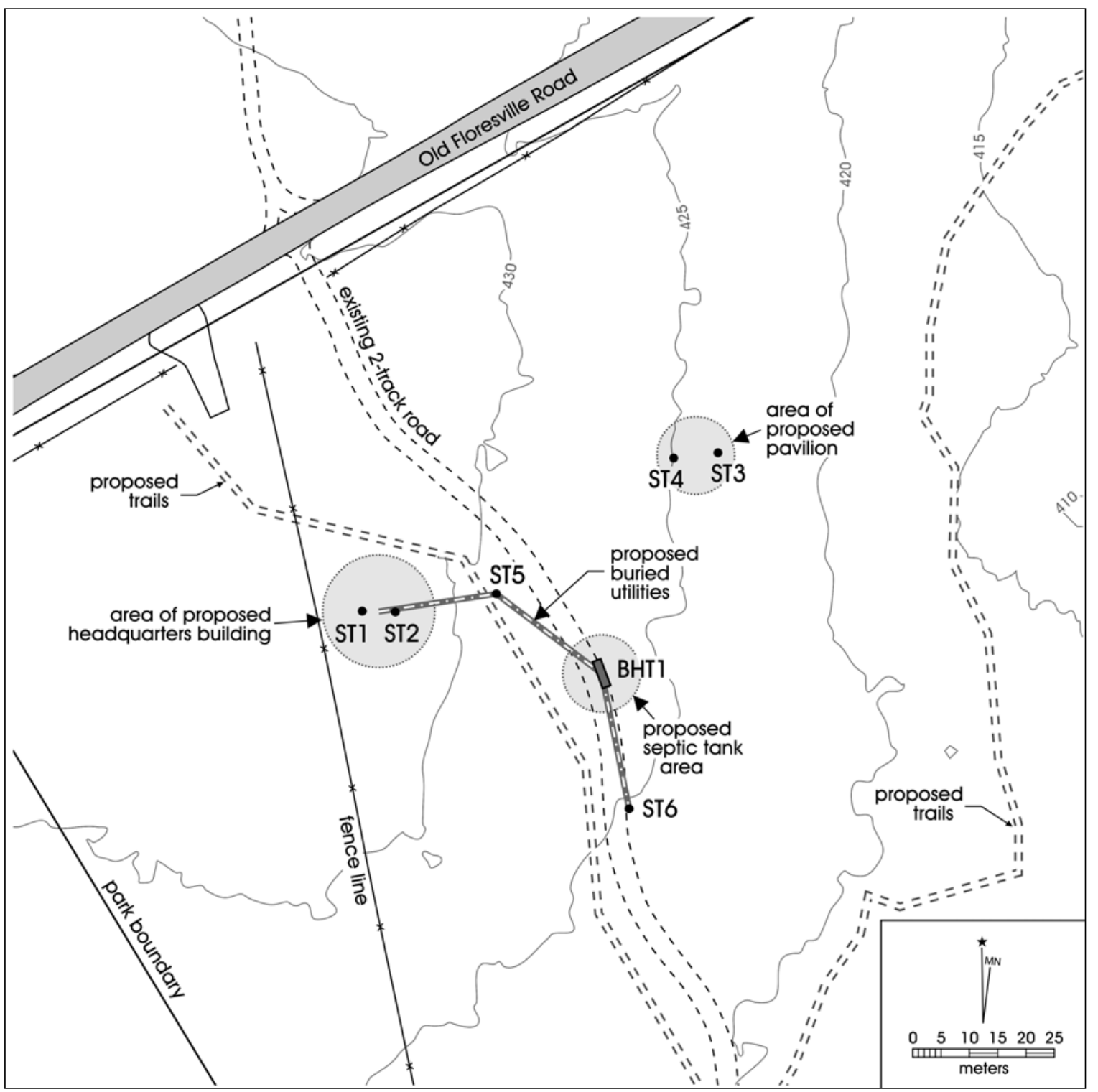

Figure 1-2. Location of planned improvements, shovel tests, and Backhoe Trench 1. 


\section{Report Organization}

This report is organized into four sections that will begin with a discussion of the background of the project area and includes the proposed improvements to the Jackson Nature Park, the project area environs, culture chronology and previous archaeological work conducted in the area. The following section will review the field and laboratory methodology employed during the archaeological investigations. The final section of the report will discuss the results of the archaeological investigations and recommendations. 



\section{Chapter 2: Project Area Background}

This chapter presents the project area background, which includes the environmental setting, culture chronology, and previous archaeology.

\section{Environmental Setting}

Site 41WN104 is located in Jackson Nature Park near Stockdale, Wilson County, Texas. The site is depicted on the Marcelinas Hills 7.5-minute USGS quadrangle map. Cibolo Creek lies about $100 \mathrm{~m}$ to the east of the project area. The site is situated on an upland terrace west of Cibolo Creek, while the eastern bank of Cibolo Creek is a broad floodplain. The elevation of site $41 \mathrm{WN} 104$ is $410 \mathrm{ft}$. The project area is within the South Texas Coastal Plains archaeological region (Blair 1950). Wilson County is within the Tamaulipan biotic province (Blair 1950). The Tamaulipan province is dominated by thorny brush such as mesquite and various acacias (Black 1989b). Within the Balconian province, oak and juniper savannas dominate the uplands and slopes, and hardwood forests line canyons and valleys (Black 1989b). Bald cypress, sycamore, black willow, pecan, black walnut, and other trees thrive along more permanent streams (Blair 1950).

The vegetation regime in the area is part of the South Texas Plains vegetation area and characterized by subtropical dryland vegetation that includes honey mesquite (Prosopis glandulosa), live oak (Quercus virginiana), blackbrush acacia (Acacia rigidula), Texas huisache (Acacia smallii) and a variety of cacti species (Black 1989b).

The climate in South-Central Texas is humid subtropical with hot and humid summers (SCTRWPG 2006). The hot weather is persistent from late May through September. The cool season begins about the first of November and extends through March. Winters are typically short and mild with light precipitation. Temperatures range from an average high of $111^{\circ} \mathrm{F}$ to an average low of $0^{\circ} \mathrm{F}$. Monthly temperature averages range from $50^{\circ} \mathrm{F}$ in January to $84^{\circ} \mathrm{F}$ in August.

Soils in the project area are Wilco-Floresville-Miguel associations that are deep, well-drained soils found in uplands (Taylor 1977). These soils are sandy and loamy soils with clayey lower layers. The soils are further classified with Wilco Series, Poth Series and Vernia Series. The Wilco
Series $(\mathrm{WcB})$ consists of loamy find sand, with 0 to 3 percent slope. The Poth Series (PtB) are loamy fine sands, with 0 to 3 percent slope. Verian Series $(\mathrm{VrC})$ soils are very gravelly loam sand with 1 to 8 percent slope.

\section{Culture Chronology}

There are four periods that are discernible by changes in hunting and gathering technologies, material culture and the arrival of non-indigenous populations: Paleoindian, Archaic, Late Prehistoric and Historic. Coherent culture chronologies of Central Texas by Collins (1995) and Prewitt (1981) are the standard summaries adhered to by many researchers. In this section, Collins' culture chronology for Central Texas $(1995,2004)$ is used as a basis with supplemental current research included as well. This section will discuss each cultural time period.

\section{Paleoindian}

The Paleoindian period is the earliest culture period recorded for the region and marks the first signs of human populations in the New World. It coincides with the end of the Pleistocene, and spans roughly from ca. 11,500-8800 BP (Collins 1995, 2004). Current research has confirmed absolute dates at three sites in Texas; the earliest is from the Aubrey site in Denton County, with radiocarbon assays of 11,542 $\pm 111 \mathrm{BP}$ and 11,590 $\pm 93 \mathrm{BP}$ (Bousman et al. 2004:48). Environmental data suggests that climate during the Late Pleistocene was wetter and cooler than the present (Mauldin and Nickels 2001; Toomey et al. 1993), though the climate became increasingly drier and warmer into the Early Holocene (Bousman 1998).

Early perceptions of Paleoindian populations generally conceptualized hunter-gatherers ranging over wide areas in pursuit of now extinct megafauna. This view of Paleoindian peoples, much like the dating of this period, is now being reassessed. While certainly exploiting Late Pleistocene megafauna, these peoples are perhaps better characterized as more generalized hunter-gatherers with subsistence including small game and plants. The Lewisville site (Winkler 1982) and the Aubrey site (Ferring 2001) possess faunal assemblages with a wide range of taxa that 
not only include large mammals but small to medium ones as well. Little information seems to be available on the consumption of plant resources during this cultural period, though according to Bousman et al. (2004) the Late Paleoindian component at the Wilson-Leonard site reflects diverse exploitation of riparian, forest and grassland species. Skeletal analysis of Paleoindian remains indicates that the diets of the Paleoindian and later Archaic hunter-gatherers may not have differed so greatly (Bousman et al. 2004, after Powell and Steele 1994).

Clovis and Folsom fluted projectile points utilized in hunting megafauna characterize material culture from early Paleoindian times. Projectile points, such as Plainview, Dalton, Angostura, Golondrina, Meserve, and Scottsbluff, are diagnostic of the late Paleoindian period. Typical site types associated with the Clovis subperiod are camp, lithic procurement, kill, cache, ritual and burial sites (Collins 1995). Meltzer and Beaver (1995) have documented 406 Clovis points in Texas. One of the earliest documented Paleoindian sites, 41RB1, was a small playa site near Miami in Roberts County, Texas (Bousman et al. 2004:15). According to radiocarbon assays the maximum age for the Miami site is 11,415 \pm 125 BP (Bousman et al. 2004:47).

\section{Archaic}

The Archaic period spans from ca. 8800 to $6000 \mathrm{BP}$. This culture period is divided into Early, Middle, and Late Archaic sub-periods. Johnson and Goode (1994) distinguish between a Late Archaic I and Late Archaic II. During the Archaic there is a shift in subsistence with a greater emphasis on the exploitation of specific local environments. Differences between phases are again marked by changes in material culture and site characteristics. Hunting strategies focus mainly on medium to small game along with the continued foraging of plant resources.

\section{Early Archaic}

According to Collins (1995) the Early Archaic spans from 8800 to 6000 BP. Early Archaic projectile point styles include Angostura, Early Split Stem, Martindale and Uvalde (Collins 1995). The climate during the Early Archaic is described as drier than the Paleoindian period with a return of grasslands (Bousman 1998). With the extinction of megafauna, the exploitation of medium to small fauna became more of a necessity. It has been postulated that the shift in climate appears to be the main cause for an apparent change in subsistence patterns.

Data recovered from the Wilson-Leonard site reveal the continuation of projectile point forms and the use of small to medium size hearths that were also present during the Paleoindian period. The appearance of earth ovens suggests another shift in subsistence patterns. Collins et al. (1998) suggest the earth ovens at the Wilson-Leonard site were used to cook wild hyacinth, along with aquatic and terrestrial resources. Information from Early Archaic human remains from Kerr County (Bement 1991) indicates a diet fairly low in carbohydrates in relation to Early Archaic populations in the Lower Pecos area. Stable-carbon isotopes also suggest a low reliance on $\mathrm{C}_{3}$ plants and animals that consume such vegetation (Johnson and Goode 1994:24).

\section{Middle Archaic}

Date ranges for the Middle Archaic span from $6000 \mathrm{BP}$ to 4000 BP (Collins 1995). Weir (1976) suggests that there was an increase in population during this sub-period. Climate was gradually drying as the onset of the Altithermal drought began. Demographic and cultural changes likely occurred in response to the hotter and drier conditions, though specific data has yet to be compiled. Middle Archaic projectile point styles include Bell, Andice, Calf Creek, Taylor, Nolan, and Travis. Johnson and Goode (1994) postulate that culture transmission from the Lower Pecos region explains the appearance of new point styles in the period.

The accepted view of Middle Archaic subsistence patterns seems to be that there was greater focus on exploitation of nuts and plants from riverine environments (Black 1989a, 1989b). The argument for the accumulation of burned rock middens during the Middle Archaic coincided with Black's notion of the exploitation of plant resources (Black 1989a; Johnson and Goode 1994). Current research has reassessed when the use of burned rock middens intensified. Data from Camp Bowie infers that intensification occurred in the later, Late Prehistoric period (Mauldin et al. 2003). Much is unknown about burial practices during this culture period, though a sinkhole in Uvalde (41UV4) contained 25-50 individuals (Johnson and Goode 1994:28). 


\section{Late Archaic}

The Late Archaic is the final phase of the Archaic period and spans from 4000-1200 BP (Collins 2004). The Late Archaic is marked by introduction of the Bulverde, Pedernales, Kinney, Lange, Marshall, Williams, Marcos, Montell, Castroville, Ensor, Frio, Fairland, and Darl projectile points. During the early part of the Late Archaic there are fluctuations in temperature and rainfall (Johnson and Goode 1994). This change in climate marks Johnson and Goode's Late Archaic II (Johnson and Goode 1994).

Some researchers state the accumulation of burned rock middens ceased at this time, though as discussed in the Middle Archaic section, current research has challenged this notion (Black and Creel 1997; Mauldin et al. 2003). In Johnson and Goode's (1994) summary of the Late Archaic, quite a bit of the discussion is devoted to the role of burned rock middens in acorn processing. Evidence of cemeteries at this time in Central and South Texas indicate increasing populations and possibly territorial boundaries (Nickels et al. 1998). Human skeletons dating to this sub-period of the Archaic have been found near the Edwards Plateau. Dental evidence shows a high rate of enamel hypoplasia indicating nutritional stress at this time (Johnson and Goode 1994). Current research indicates higher rates of enamel hypoplasia in coastal populations as opposed to inland populations where signs of nutritional stress are lower (Munoz 2004)

\section{Late Prehistoric}

This period begins ca. 1200 BP (Collins 1995, 2004) and includes the Austin and Toyah Phases. The term Late Prehistoric is commonly used to designate the period following the Late Archaic in Central and South Texas. A series of distinctive traits marks the shift from the Archaic to the Late Prehistoric period, including the technological shift to the bow and arrow and the introduction of pottery.

Nickels and Mauldin (2001) suggest that at the beginning of this period, environmental conditions were warm and dry, but by $1000 \mathrm{BP}$, more mesic conditions appear to accelerate. Subsistence practices remain relatively unchanged, especially during the Austin Phase (Collins 1995). Projectile point styles associated with the Austin Phase include Edwards and Scallorn types while in the Toyah Phase the Perdiz projectile point is prevalent (Collins 1995).
Most researchers agree the early Late Prehistoric period was a time of population decrease (Black 1989a:32). Radiocarbon data has revealed that a number of burned rock middens in Central Texas were used long after the Archaic and throughout the Late Prehistoric. Moreover, the "heyday of middenery began after A. D. 1 [1949 BP] and peaked during the Late Prehistoric" (Black and Creel 1997:273). In addition, radiocarbon dates from Camp Bowie middens concur with arguments set forth by Black and Creel (1997) that burned rock middens are primarily a Late Prehistoric phenomena (Mauldin et al. 2003).

Beginning rather abruptly at about $650 \mathrm{BP}$, a shift in technology occurred. This shift is characterized by the introduction of blade technology, the first ceramics in Central Texas (bone-tempered plainwares), the appearance of Perdiz arrow points, and alternately beveled bifaces (Black 1989a:32). Prewitt (1981) suggests this technology encroached from North-Central Texas. Patterson (1988), however, notes the Perdiz point was first seen in Southeast Texas by about $1350 \mathrm{BP}$, and was introduced to the west some 600-700 years later.

Ricklis (1995) contends that ceramics became a part of the archaeological record in Central Texas beginning about 650 BP. Early ceramics in Central Texas are associated with Toyah Phase components and referred to as Leon Plain. The earliest dates for Leon Plain are relative and based on associations with "Toyah" assemblages. Characteristics of Leon Plain include particular vessel forms (bowls, jars, and ollas) that are undecorated, bone-tempered, and possess oxidized exterior surfaces (Ricklis 1995). Additional traits include burnished or floated surfaces. Although there are a set of attributes associated with Leon Plain, there does tend to be notable variation within the type (Black 1986; Johnson 1994; Kalter et al. 2005). Any variation is typically attributed to differences in manufacturing techniques and cultural affiliation. Stable carbon and nitrogen isotope data suggest that vessels were utilized in the processing of deer/bison bone grease or fat, and mesquite bean (Quigg and Peck 1995).

Settlement shifts into rockshelters such as Scorpion Cave in Medina County (Highley et al. 1978) and Classen Rockshelter in northern Bexar County (Fox and Fox 1967) have been noted during this time. Cemeteries from this period often reveal evidence of conflict (Black 1989a:32). 


\section{Previous Archaeological Investigations}

The proposed improvements are planned within the boundaries of $41 \mathrm{WN} 104$, a multi-component archaeological site documented in 2001 (Marek 2001). The site is located within the boundaries of the Jackson Nature Park. $41 \mathrm{WN} 104$ was recorded during an archaeological survey conducted for the development of Jackson Nature Park. The site measured $305 \mathrm{~m}$ (north-south) by approximately $243 \mathrm{~m}$ (east-west) and is described by Marek as a large and deep scatter of lithic debris. Reportedly, the site extends beyond the current park boundaries to the west and north. During the archaeological investigations, shovel tests were excavated along three transects that traversed the northern part of the park property (oriented southwest-northeast), the western edge of the property (oriented north-south) and the eastern portion of the property (oriented north-south). No features or diagnostic material were identified during the survey of $41 \mathrm{WN104}$. Analysis of the cultural material failed to indicate any apparent patterns. The SAL and NRHP status of the site was undetermined during its initial recording in 2001.

At the time of its recording the site contained a historic component as well. The historic component of the site consisted of a wooden farmhouse (reportedly 70 years old), metal cistern (inscribed with "1949 11-26 Urban Lopez") and historic dump (see Marek 2001). Five shovel tests were excavated on this portion of the site; they contained historic (early twentieth century) and prehistoric cultural material. Further work was not recommended on this portion of the site and the structure was demolished shortly thereafter.

In 2001, the anticipated impacts to the site included the installation of a fence on the western boundary, upgrade of the existing dirt road, construction of a picnic area (Marek 2001) and clearing of trails. The more extensive impacts that were to occur to the site at that time consisted of an amphitheater and visitor's center. Shovel testing efforts in preparation for these improvements did not sufficiently test areas where current improvements are to take place; therefore, additional testing of the site was required.

Other sites in the vicinity include 41WN27 and 41WN28. Site 41WN27 was recorded in 1968 (Hsu and Ralph 1968) and is approximately $350 \mathrm{~m}$ southeast of $41 \mathrm{WN} 104$. It consisted of historic and prehistoric components. 41WN28, located approximately $400 \mathrm{~m}$ northeast of $41 \mathrm{WN} 104$ was reported as a lithic scatter with the presence of historic material as well (Hsu and Ralph 1968; THC 2006). 


\section{Chapter 3: Field and Laboratory Methods}

The principal goal of the testing of selected portions of $41 \mathrm{WN} 104$ was to identify whether significant intact cultural resources exist within the specific areas impacted by the proposed improvements and whether those resources contribute to the NRHP and SAL eligibility of the site.

The significance testing included shovel testing as the principal subsurface investigative method within the area of the two building pads and the easement of the utilities trenches. Two shovel tests were proposed to be excavated within the headquarters pad area, and another two shovel tests were proposed for the pavilion pad to a depth of $100 \mathrm{~cm}$ below surface (cmbs). In the Scope of Work (SOW), shovel test excavations were proposed every $20 \mathrm{~m}$ along the $330-\mathrm{ft}$. utilities easement. The day of the fieldwork, the length of utilities easement was reduced to approximately $200 \mathrm{ft}$. $(60 \mathrm{~m})$ to include only two lines instead of three. The newly proposed utility route ran from the business headquarters to the proposed septic tank area (approximately $40 \mathrm{~m}$ ) and then south along the existing two-track road $(20 \mathrm{~m})$. This reduced the number of shovel tests that were originally proposed in the SOW.

Given that projected subsurface impacts are to extend to only $12 \mathrm{in}$. (approximately $30 \mathrm{~cm}$ ) below the surface, shovel tests excavated in the utilities easement were $30 \mathrm{~cm}$ in diameter and reached a maximum depth of $60 \mathrm{cmbs}$, if not otherwise prevented. The shovel tests were excavated in $10-\mathrm{cm}$ levels, and the deposits screened through $1 / 4-\mathrm{in}$. hardware cloth. The number of artifacts recovered by level and the type and texture of the soil encountered in each level were noted on standard shovel test forms. All artifacts encountered in each level were bagged by provenience and returned to the CAR laboratory for processing, analysis, and final curation.

A single backhoe trench was excavated to a depth of $1.5 \mathrm{~m}$ below surface and extended $5.0 \mathrm{~m}$ in length. A five-gallon bucket of dirt (approximately $0.2 \mathrm{~m}^{3}$ ) was extracted from each cubic meter of matrix and screened through 1/4-in. hardware cloth. A segment of one wall of the trench was profiled. The location of the backhoe trench and shovel tests were mapped with a GPS unit.
All archaeological materials recovered during testing were fully analyzed, described, and reported. All cultural materials and records obtained and generated during the project were prepared in accordance with federal regulation 36 CFR part 79, and THC requirements for State Held-in-Trust collections. Artifacts processed in the CAR laboratory were washed, air-dried, and stored in 4-mm, zip-locking, archival-quality bags. Acid-free labels were placed in all artifact bags. Each label contains provenience information and a corresponding lot number written in archival ink, with pencil or laser-printed. The projectile points were labeled with permanent ink over a clear coat of acrylic and covered by another acrylic coat. In addition, a small sample of unmodified debitage from each lot was labeled with the appropriate provenience data. Artifacts were separated by class and stored in acid-free boxes. Digital photographs were printed on acid-free paper and labeled with archivally appropriate materials and placed in archival-quality sleeves. All field forms were completed with pencil. 



\section{Chapter 4: Results}

In this chapter, we discuss the results of the shovel testing and backhoe trenching conducted on $41 \mathrm{WN} 104$. Six shovel tests and a single backhoe trench were excavated as a part of the archaeological investigations conducted by CAR on July 25, 2006 (see Figure 1-2). Shovel tests were placed in the proposed pavilion and business headquarters facilities and along planned utility lines. A backhoe trench was excavated in the location of the proposed septic tank.

\section{Shovel Tests}

Shovel Tests (STs) 1 and 2 were excavated in the area of the proposed business headquarters area (Figure 4-1). This area is located in the western portion of the property and was heavily overgrown with mesquite and prickly pear. Shovel Test 1 reached a depth of $100 \mathrm{cmbs}$, while ST 2 reached a depth of $80 \mathrm{cmbs}$. Soil matrix in both shovel tests consisted of loose, soft sand that ranged in color from a yellowish brown to gray brown (10YR 5/3 and 4/3) in the first $50 \mathrm{cmbs}$. In the lower $50 \mathrm{~cm}$, the soils became increasingly hard and consisted of sandy clay. The color of the soil remained similar despite the increase in clay content. Level 9 of ST 1 exhibited a change in color that was reddish clay mottled with gray clay. Shovel Test 1 contained debitage $(\mathrm{n}=17)$ and burned rock $(\mathrm{n}=89 ; 239 \mathrm{~g})$ (Table 4-1). Cultural material recovered from ST 2 included debitage $(\mathrm{n}=25)$ and burned rock $(\mathrm{n}=115 ; 447 \mathrm{~g})$. Soils in the area appeared to be intact and not disturbed.

Two shovel tests were excavated (STs 3 and 4) in the pavilion area. The area was clear of vegetation, east of the two-track road (Figure 4-2). As outlined in the Scope of Work, shovel tests placed in this area were intended to reach a maximum depth of $100 \mathrm{cmbs}$, but due to the compact soils encountered in both shovel tests, they reached terminal

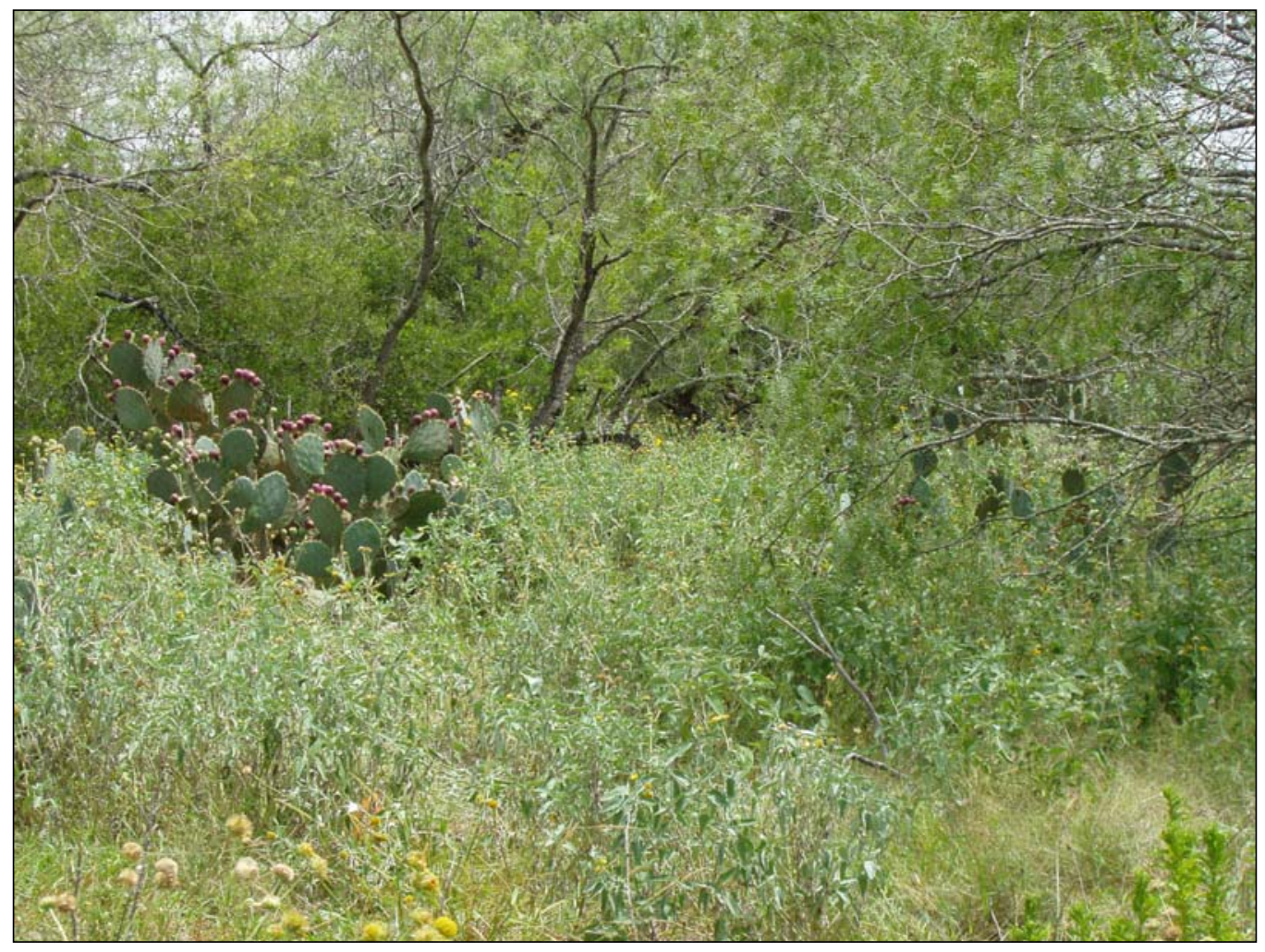

Figure 4-1. Area of proposed business headquarters (facing south). 
Table 4-1. Distribution of Artifacts by Shovel Test and Level

\begin{tabular}{|c|c|c|c|c|c|c|}
\hline & Level & Debitage & Burned Rock & *Burned Rock Wt. (g) & Projectile Points & Total \\
\hline \multirow{10}{*}{ Shovel Test 1} & 1 & 2 & 3 & 0.6 & 0 & 5 \\
\hline & 2 & 1 & 1 & 1.2 & 0 & 2 \\
\hline & 3 & 3 & 4 & 0.7 & 0 & 7 \\
\hline & 4 & 0 & 15 & 12.5 & 0 & 15 \\
\hline & 5 & 3 & 11 & 13.9 & 0 & 14 \\
\hline & 6 & 0 & 10 & 49.7 & 0 & 10 \\
\hline & 7 & 2 & 13 & 50.9 & 0 & 15 \\
\hline & 8 & 4 & 22 & 65.4 & 0 & 26 \\
\hline & 9 & 2 & 7 & 6.6 & 0 & 9 \\
\hline & 10 & 0 & 3 & 38.2 & 0 & 3 \\
\hline \multicolumn{2}{|c|}{ Subtotal } & 17 & 89 & 239.7 & $\mathbf{0}$ & 106 \\
\hline \multirow{8}{*}{ Shovel Test 2} & 1 & 1 & 19 & 13.9 & 0 & 20 \\
\hline & 2 & 0 & 9 & 32 & 0 & 9 \\
\hline & 3 & 3 & 19 & 49.2 & 0 & 22 \\
\hline & 4 & 1 & 8 & 16.1 & 0 & 9 \\
\hline & 5 & 9 & 27 & 185.3 & 0 & 36 \\
\hline & 6 & 5 & 19 & 129.7 & 0 & 24 \\
\hline & 7 & 2 & 9 & 9 & 0 & 11 \\
\hline & 8 & 4 & 5 & 12.6 & 0 & 9 \\
\hline \multicolumn{2}{|c|}{ Subtotal } & 25 & 115 & 447.8 & $\mathbf{0}$ & 140 \\
\hline \multirow{4}{*}{ Shovel Test 3} & 1 & 0 & 10 & 19 & 0 & 10 \\
\hline & 2 & 0 & 9 & 45.1 & 0 & 9 \\
\hline & 4 & 0 & 6 & 7.2 & 0 & 6 \\
\hline & 5 & 0 & 2 & 0.3 & 0 & 2 \\
\hline \multicolumn{2}{|c|}{ Subtotal } & $\mathbf{0}$ & 27 & 71.6 & $\mathbf{0}$ & 27 \\
\hline \multirow{5}{*}{ Shovel Test 4} & 1 & 0 & 12 & 22.6 & 0 & 12 \\
\hline & 2 & 0 & 7 & 1.9 & 1 & 8 \\
\hline & 3 & 1 & 2 & 0.2 & 0 & 3 \\
\hline & 4 & 0 & 6 & 10.7 & 0 & 6 \\
\hline & 5 & 0 & 2 & 5.6 & 0 & 2 \\
\hline \multicolumn{2}{|c|}{ Subtotal } & 1 & 29 & 41 & 1 & 31 \\
\hline \multirow{4}{*}{ Shovel Test 5} & 1 & 0 & 10 & 51.8 & 0 & 10 \\
\hline & 2 & 0 & 12 & 73.6 & 0 & 12 \\
\hline & 3 & 2 & 16 & 15.2 & 0 & 18 \\
\hline & 4 & 0 & 1 & 1 & 0 & 1 \\
\hline \multicolumn{2}{|c|}{ Subtotal } & 2 & 39 & 141.6 & $\mathbf{0}$ & 41 \\
\hline \multirow{3}{*}{ Shovel Test 6} & 3 & 4 & 8 & 3.7 & 1 & 13 \\
\hline & 4 & 0 & 1 & 1.6 & 0 & 1 \\
\hline & 6 & 1 & 3 & 5.1 & 0 & 4 \\
\hline \multicolumn{2}{|c|}{ Subtotal } & 5 & 12 & 10.4 & 1 & 18 \\
\hline \multicolumn{2}{|l|}{$\overline{\text { Grand Total }}$} & 50 & 311 & $\overline{952.1}$ & 2 & 363 \\
\hline
\end{tabular}

* Burned Rock weight is not included in Grand Total 


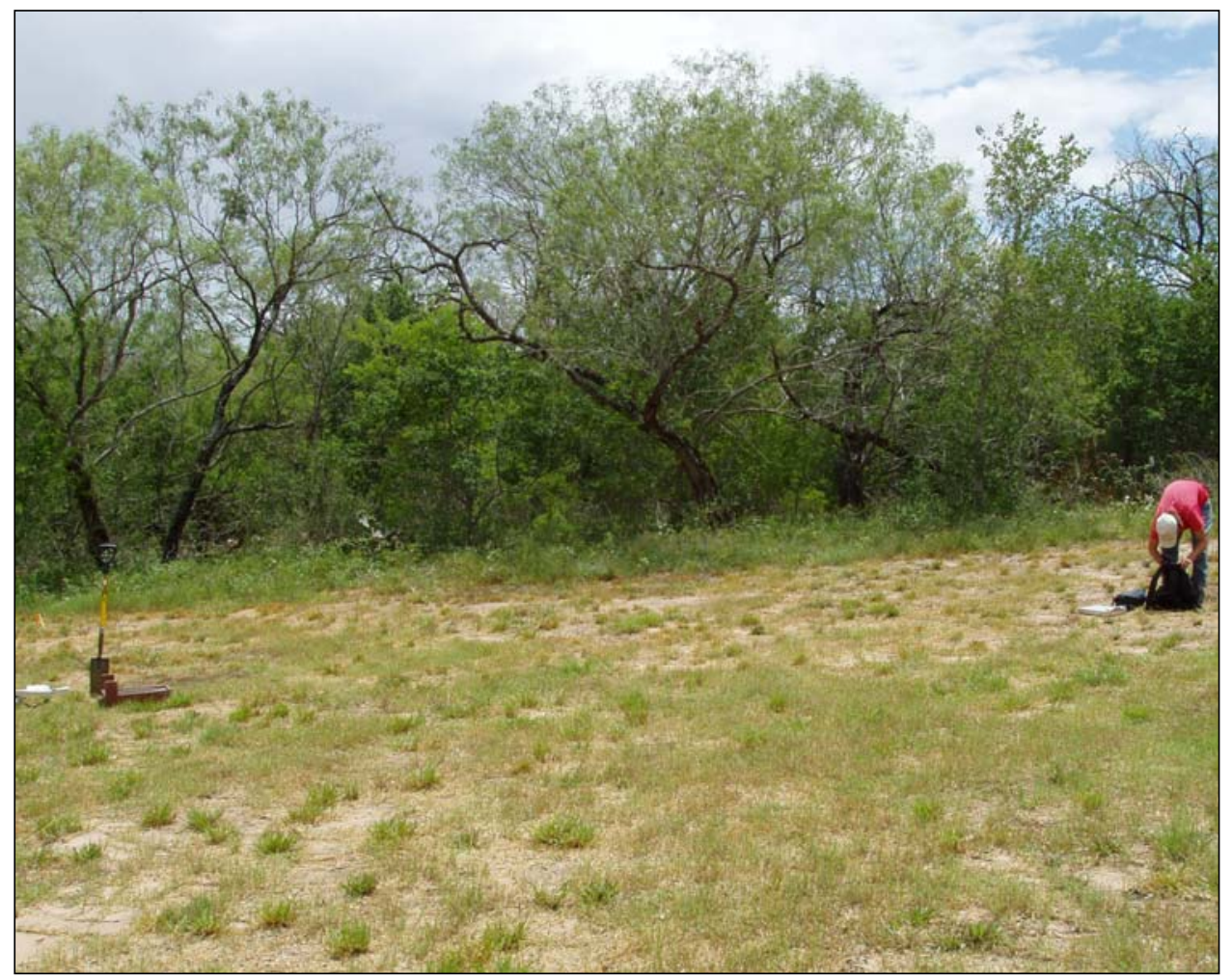

Figure 4-2. Shovel testing in proposed pavilion area.

depths of only $60 \mathrm{cmbs}$. Sandy soils (brown 10YR 5/3) were present in both shovel tests in the first two levels. The remaining portions of the shovel tests consisted of very compacted sand (with some mottling present), possibly hardened by lack of moisture. The density of artifacts is lower in the pavilion area than in the business headquarters area. Shovel Test 3 contained only burned rock $(n=27$; $71 \mathrm{~g})$. Burned rock $(\mathrm{n}=29 ; 41 \mathrm{~g})$ and one piece of debitage were present in Shovel Test 4 . The stem of an untyped dart point that appeared to be a Late Archaic form (Figure 4-3[a]) was also recovered in Shovel Test 4 (Level 2). Prior clearing of vegetation in this area for picnic tables may have caused minimal disturbance in the upper $5-10 \mathrm{~cm}$ of soils.

The proposed utility line was the third area to be shovel tested (STs 5 and 6). As mentioned in Chapter 1, the length and route changed from that proposed in the SOW. The northeastern segment of the proposed utility route crosses an area of dense vegetation. A path along the proposed route was cleared from the western edge of the business headquarters area to the existing two-track road with a backhoe (Figure 4-4). Shovel Test 5 was placed in this segment of the proposed route and excavated to a depth of
$60 \mathrm{cmbs}$. Soil in this shovel test was dark yellowish brown (10YR 4/4) sandy clay that was compact and heavily mottled with red and yellow clay in Levels 4 through 6 . Roots were present in Levels 1 through 4 and gravels were

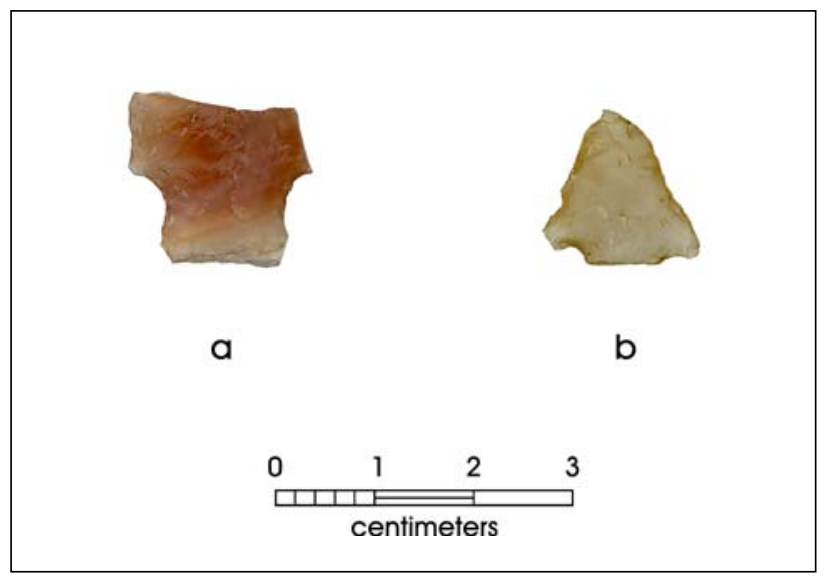

Figure 4-3. Projectile points recovered from 41WN104: (a) Late Archaic dart point; (b) Late Prehistoric unidentifiable arrow point 
present in the remaining levels. Artifacts recovered from this shovel test (see Table 4-1) consisted mostly of burned rock $(\mathrm{n}=39 ; 141 \mathrm{~g})$ and two pieces of debitage.

Shovel Test 6 was excavated at the southern portion of the proposed utility route, south of the septic tank area (Figure 4-5), on the two-track road. It reached the targeted depth of $60 \mathrm{cmbs}$. The soil encountered in Shovel Test 6 appeared to be disturbed in the first three levels and may be fill associated with improvements made to the two-track road following Marek's investigations in 2001. The soil in Levels 1 through 3 was brown (10YR 5/3), compact sand with red and yellow mottling and an abundance of pebbles and cobbles ( 50 percent). The remainder of the levels consisted of brown, compact, sandy clay with fewer inclusions. Debitage $(\mathrm{n}=5)$, burned rock $(\mathrm{n}=12 ; 10 \mathrm{~g})$, one arrow point fragment (Figure 4-3[b]) and a .22-caliber shell casing were recovered from this shovel test (see Table 4-1). The untypable Late Prehistoric arrow point was recovered in Level 3 with the shell casing, clearly indicating mixed deposits.

The combined count of artifacts recovered in shovel tests was 363 and was comprised of lithic debitage, burned rock and two projectile points. Though there are a larger number of burned rock artifacts than chipped stone artifacts, they are mostly small fragments measuring ca. $10 \mathrm{~mm}$. There are a very few large pieces that measure approximately $62 \mathrm{~mm}$ in size. Table 4-1 presents the artifacts recovered from shovel test excavations.

The two recovered projectile points clearly date the tested portions of the $41 \mathrm{WN} 104$ to the Late Archaic to Late Prehistoric. Figure 4-6 illustrates the average number of burned rock (blue line) and debitage (red line) recovered per excavated level of shovel tests. The average amount of burned rock and debitage is highest in Level 8.

\section{Backhoe Trench 1}

Backhoe Trench (BHT) 1 was excavated in the area of the proposed septic tank (see Figure 1-2). The trench measured $5 \mathrm{~m}$ in length and reached a maximum depth of $1.5 \mathrm{~m}$. The stratigraphy seen in the western wall of the backhoe trench was profiled (Figure 4-7). Three main stratigraphic zones were distinguished. Zone 1 consisted of a brown (10YR $4 / 3$ ), sandy loam and extended from ground surface to

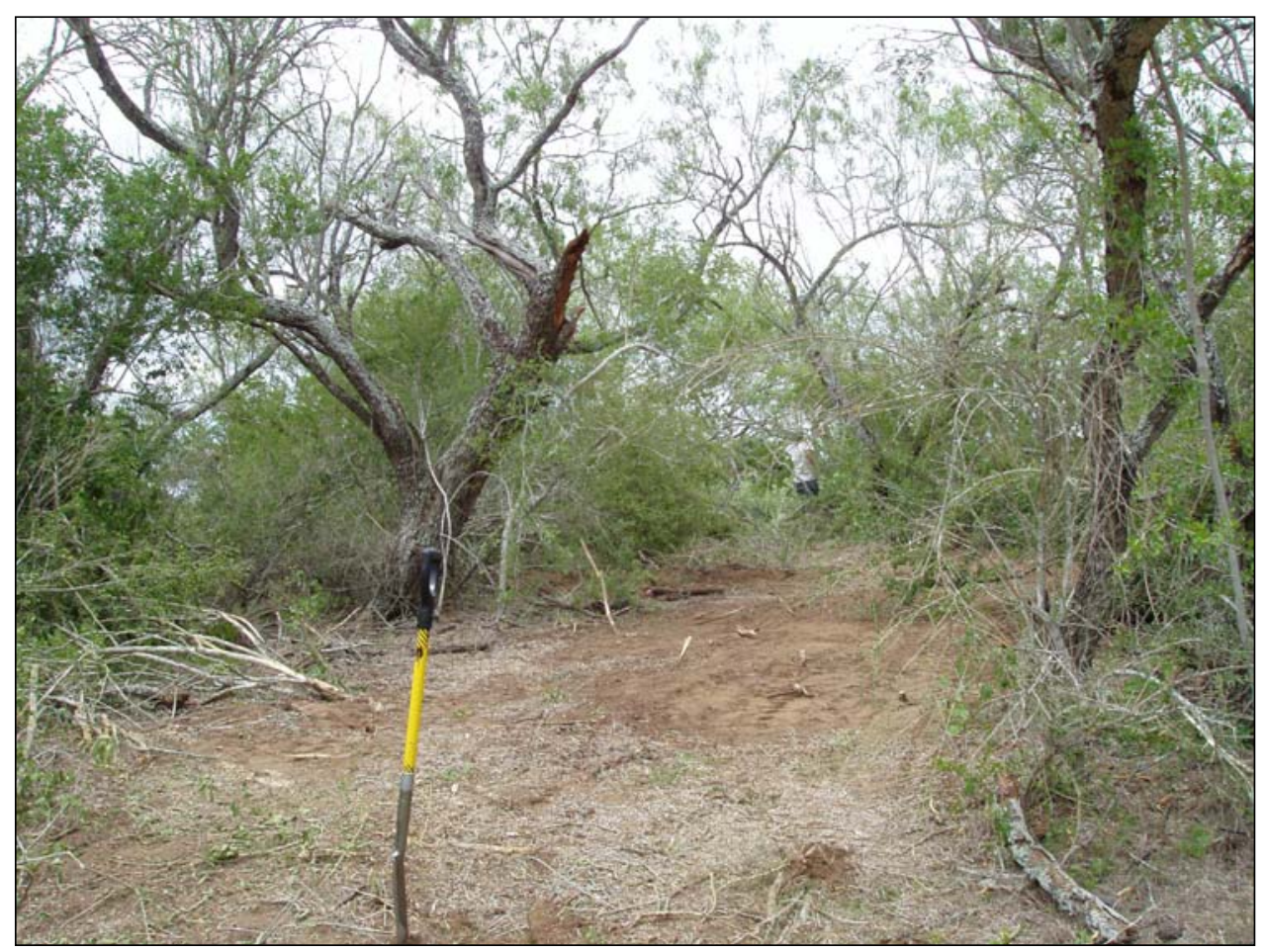

Figure 4-4. Shovel testing along proposed utility line between proposed business headquarters facility and septic tank. 


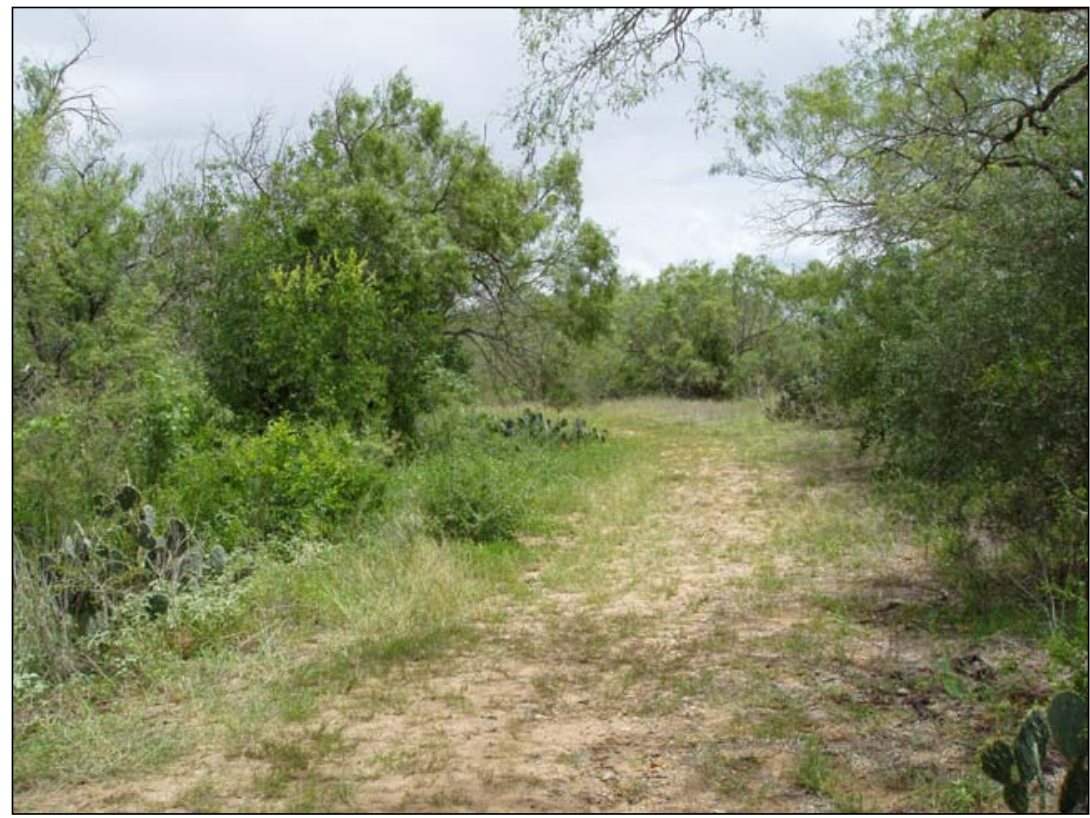

Figure 4-5. Proposed route of utility line running south from septic tank along two-track road.

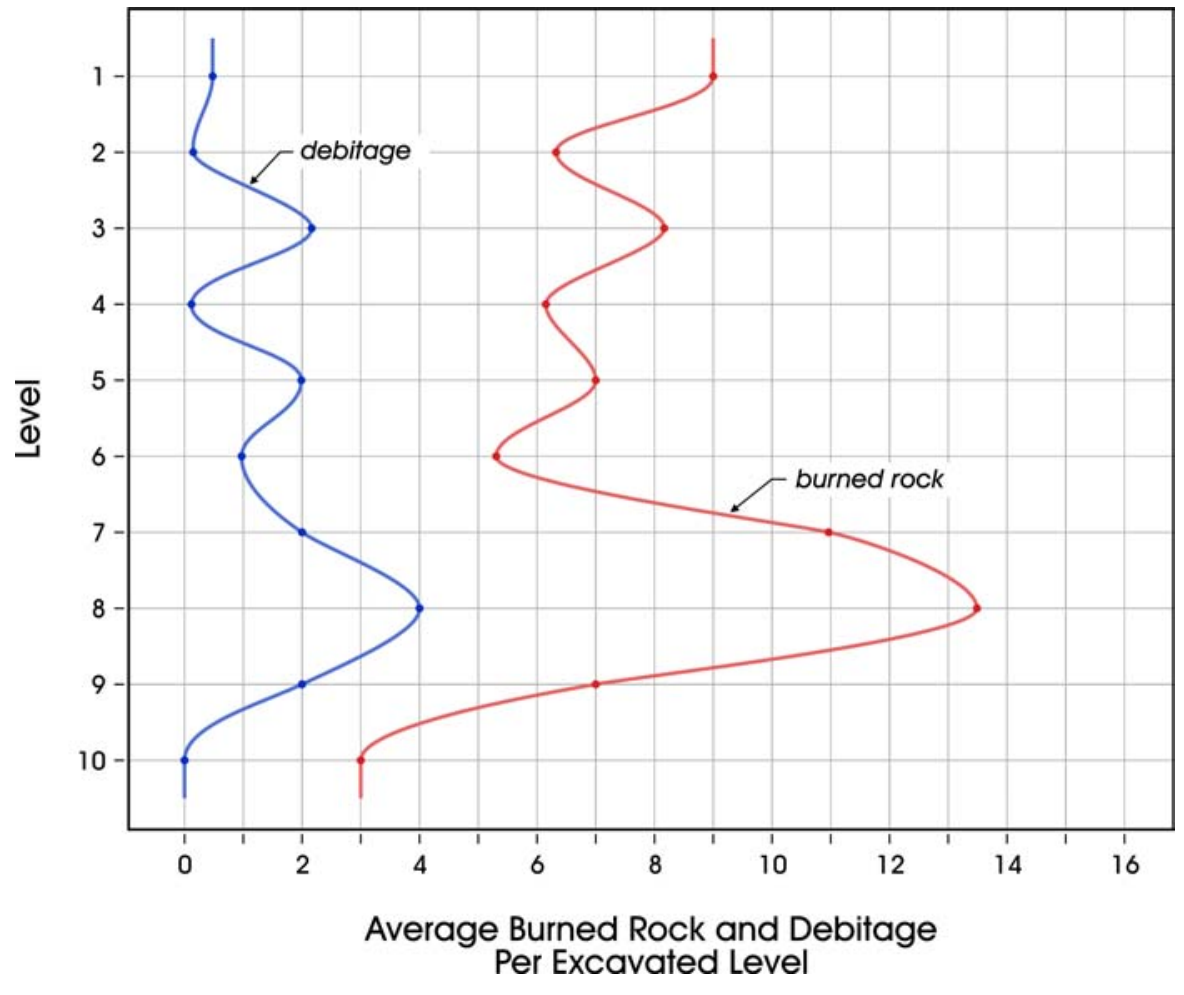

Figure 4-6. Average burned rock and debitage recovered from shovel tests, per excavated level. 


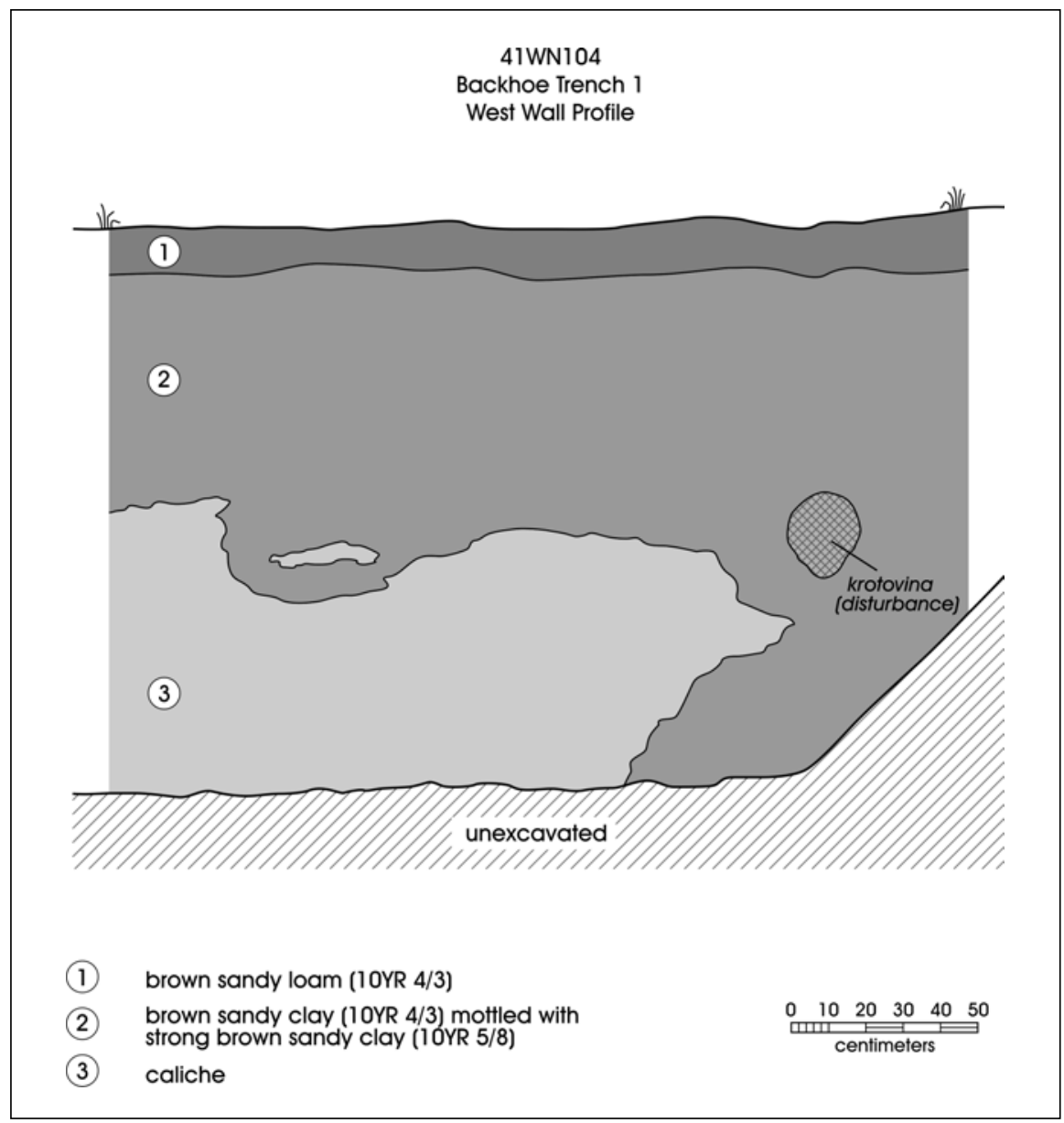

Figure 4-7. Profile of a portion of the west wall of Backhoe Trench 1.

15 cmbs. Zone 2 was a brown (10YR 4/3), sandy loam mottled with a strong brown (10YR 5/8); the maximum depth of the layer varied from 70 to $140 \mathrm{cmbs}$ (in southern portion of the trench). Zone 2 soil was blocky and compacted and a krotovina was present in Zone 2 and difficult to screen. Caliche was present near its base, while Zone 3 was an entirely comprised of caliche. As discussed in the Chapter 3, a five gallon bucket of dirt (approximately $0.2 \mathrm{~m}^{3}$ ) was extracted from each cubic meter of matrix and screened through $1 / 4$-in. hardware cloth. During screening three pieces of debitage were encountered from the matrix derived from Zone 1, but not collected. No artifacts were observed in the trench walls during profiling. The only cultural material was observed in the backdirt of the backhoe trench excavation.

\section{Summary}

Six shovel tests and one backhoe trench were excavated in three areas of the Jackson Nature Park that will be impacted by planned improvements. All of the shovel test excavations contained cultural material consisting of burned rock $(n=311)$ and debitage $(n=50)$. It appears the majority of cultural material, particularly debitage, was recovered in the area of the proposed business headquarters. Shovel testing in the pavilion area recovered only one piece of debitage and 50 pieces of burned rock (113 g). The dart point recovered from Shovel Test 4 (Level 2) was identified as a Late Archaic form. Shovel testing along the route of the proposed utility line (STs 5 and 6 ) revealed seven pieces of debitage and 52 pieces of burned rock (152 g). The arrow point from Shovel Test 6 (Level 3) dates to the Late Prehistoric and was associated with disturbed soils that also contained a bullet casing. BHT 1 failed to encounter in situ materials or features. 


\section{Chapter 5: Conclusions and Recommendations}

On July 25, 2006 the Center for Archaeological Research at The University of Texas at San Antonio conducted archaeological investigations in the confines of Jackson Nature Park, located in Wilson County, Texas. The park is also the location of site 41WN104 that was identified by Marek in 2001 (Marek 2001). Planned improvements to the park initiated intensive pedestrian survey in the form of shovel testing and backhoe trenching of three areas that will include a business headquarters facility, pavilion area, and a septic tank. Shovel tests were also excavated along a proposed utility line connecting the business headquarters facility to the septic tank and south along the existing two-track road. The vicinity of these specific areas of impact was not sufficiently investigated during the previous work at the site.

Investigations in the park failed to encounter any intact features. The western portion of the site in the area of the proposed business headquarters appears to have the highest density of cultural material, down to one meter below surface. Burned rock and a proximal dart point fragment were recovered from the proposed pavilion area. Along the two-track road there appears to be some disturbance associated with road improvements. An arrow point fragment was recovered from disturbed deposits at a depth of 20-30 cmbs. In sum, shovel testing revealed cultural material dating to possibly the Late Archaic and Late Prehistoric but there were no intact features encountered.

The planned improvements that will be occurring in the Jackson Nature Park will impact three areas that include a headquarters building pad (30-x-60 ft), a pavilion pad (30-x-40 ft) and a 10-x-10-ft. and 9-ft. deep area excavated for the installation of the septic tank. The depth of the disturbances associated with the pads is not anticipated to exceed 6 in. $(15 \mathrm{~cm})$. In addition, one facility will be connected with utilities installed in a combined total of $200 \mathrm{ft}$. of trenching. The trenches will be 12 in. $(30 \mathrm{~cm})$ wide and 12 in. deep.

Though cultural material was not encountered in situ during the excavation of BHT 1, soils did appear undisturbed. Shovel testing along the proposed utility route revealed disturbance of at least $30 \mathrm{cmbs}$ (the proposed depth of the utility trenching). Intact soils are evident in the area of the proposed headquarters pad to a depth of at least one meter and minimal disturbance is noted in the proposed pavilion area $(5 \mathrm{cmbs})$. Due to the failure to locate features during the testing of the proposed improvement areas, we do not recommend further work. We suggest that the proposed improvements will not impact significant cultural deposits and therefore the construction should proceed as planned. However, if construction plans change, including the route of the utilities, additional testing may be necessary to test in hitherto uninvestigated portions of the park. 



\section{References Cited}

Bement, L. C.

1991 The Thunder Valley Burial Cache: Group Investment in a Central Texas Sinkhole Cemetery. Plains Anthropologist 36(135):97-109.

Black, S. L.

1986 The Clemente and Herminia Hinojosa Site, 41JW8: A Toyah Horizon Campsite in Southern Texas. Special Report, No. 18. Center for Archaeological Research, The University of Texas at San Antonio.

Black, S. L.

1989a Central Texas Plateau Prairie. In From the Gulf Coast to the Rio Grande: Human Adaptations in Central, South and Lower Pecos Texas, by T. R. Hester, S. L. Black, D. G. Steele, B. W. Olive, A. A. Fox, K. J. Reinhard and L. C. Bement, pp. 17-38. Research Series No. 33. Arkansas Archeological Survey, Fayetteville.

1989b Environmental Setting. In From the Gulf Coast to the Rio Grande: Human Adaptations in Central, South and Lower Pecos Texas, by T. R. Hester, Steve L. Black, D. G. Steele, B. W. Olive, Anne A. Fox, K. J. Reinhard and L. C. Bement, pp. 17-38. Research Series No. 33. Arkansas Archeological Survey, Fayetteville.

Black, S. L. and D. G. Creel

1997 The Central Texas Burned Rock Midden Reconsidered. In Hot Rock Cooking on the Greater Edwards Plateau: Four Burned Rock Midden Sites in West Central Texas, by Steve L. Black, Linda W. Ellis, Darrell G. Creel, and Glenn T. Goode, pp. 269-305. Studies in Archeology 2. Texas Archeological Research Laboratory, The University of Texas at Austin.

Blair, W. F.

1950 The Biotic Provinces of Texas. Texas Journal of Science 2(1):93-117.

Bousman, B. C.

1998 Paleoenvironmental Change in Central Texas: The Palynological Evidence. Plains Anthropologist 43(164): 201-219

Bousman, B. C., B. W. Baker and A. C. Kerr

2004 Paleoindian Archeology in Texas. In The Prehistory of Texas, edited by Timothy K. Perttula, pp. 15-97. Texas A\&M University Press, College Station.

Collins, M. B.

1995 Forty Years of Archaeology in Texas. Bulletin of the Texas Archeological Society 66:361-400.

2004 Archeology in Central Texas. In The Prehistory of Texas, edited by Timothy K. Perttula, pp.101-126. Texas A\&M University Press, College Station.

Collins, M. B., J. Guy and S. W. Dial

1998 The Archaic Period, 8800 to 1300 B. P. In Wilson-Leonard: An 11,000-year Archaeological Record of Hunter-Gatherers in Central Texas. Volume I: Introduction, Background and Syntheses, edited by Michael B. Collins, pp. 211-270. Studies in Archeology 31. Texas Archeological Research Laboratory, The University of Texas at Austin. 
Collins, M. B., D. B. Hudler and S. L. Black

2003 Pavo Real (41BX52): A Paleoindian and Archaic Camp and Workshop on the Balcones Escarpment, South-Central Texas. Studies in Archeology 41. Texas Archeological Research Laboratory, The University of Texas at Austin.

Ferring, C. R.

2001 The Archaeology and Paleoecology of the Aubrey Clovis Site (41DN479) Denton County, Texas. Center for Environmental Archaeology. Department of Geography, University of North Texas.

Fox, A. A., and D. E. Fox

1967 The Classen Rockshelter, 41BX23. Manuscript on file, Center for Archaeological Research, The University of Texas at San Antonio.

Highley, C. L., C. Graves, C. Land, and G. Judson

1978 Archeological Investigations at Scorpion Cave (41ME7) Medina County, Texas. Bulletin of the Texas Archeological Society 49:139-194.

Hsu, D. P. and R. W. Ralph

1968 An Appraisal of the Archaeological Resources of Cibolo Reservoir, Wilson County, Texas. Archaeological Survey Report No. 1. Texas State Building Commission and Texas State Water Development Board, Austin.

Johnson, L.

1994 The Life and Times of Toyah-Culture Folk: The Buckhollow Encampment Site 41KM16, Kimble County, Texas. Office of the State Archeologist Report 38. Austin, Texas.

Johnson, L. and G. T. Goode

1994 A New Try at Dating and Characterizing Holocene Climates, as well as Archaeological Periods, on the Eastern Edwards Plateau. Bulletin of the Texas Archeological Society 65:1-51.

Kalter, A. J., R. M. Rogers and M. N. Smith

2005 Analysis and Reporting for 41FY135, the Sandbur Site, Fayette County, Texas. Document No. 020388, PBS\&J. Archeological Studies Program, Report 73. Environmental Affairs Division, Texas Department of Transportation, Austin.

Marek, M.

2001 Archaeological Survey for Jackson Nature Park, Wilson County, Texas. Texas Historical Commission Permit No. 2598. Archeological Consultant, Wallis, Texas.

Mauldin, R. P., and D. L. Nickels

2001 An Archaeological Survey of Twin Buttes Reservoir, Tom Green County, Texas. Archaeological Survey Report, No. 300. Center for Archaeological Research, The University of Texas at San Antonio.

Mauldin, R. P., D. L. Nickels, and C. J. Broehm

2003 Archaeological Testing to Determine the National Register Eligibility Status of 18 Prehistoric Sites on Camp Bowie, Brown County, Texas. Archaeological Survey Report, No. 334. Center for Archaeological Research, The University of Texas at San Antonio. 
Melzer, D. J. and Michael R. Bever

1995 Paleoindians of Texas: An Update on the Texas Clovis Fluted Point Survey. Bulletin of the Texas Archeological Society 66:47-81.

Munoz, C. M.

2004 Native American Adaptation on the Texas Coastal Plain: A Study of the Dentition from Thirteen Prehistoric and Historic Cemetery Sites. Unpublished Master's thesis, Department of Anthropology, The University of Texas at San Antonio.

Nickels, D. L., C. B. Bousman, J. D. Leach, and D. A. Cargill

1998 Test Excavations at the Culebra Creek Site, 41BX126, Bexar County, Texas. Archaeological Survey Report, No. 265. Center for Archaeological Research, The University of Texas at San Antonio. Archeology Studies Program, Report 3. Environmental Affairs Division, Texas Department of Transportation, Austin.

Nickels, D. and R. Mauldin

2001 The Project Environment. In An Archaeological Survey of Twin Buttes Reservoir, Tom Green County, Texas, edited by Raymond P. Mauldin and David L. Nickels, pp. 25-38. Archaeological Survey Report, No. 300. Center for Archaeological Research, The University of Texas at San Antonio.

Patterson, L. W.

1988 Chronology of Arrow Point Types in South Texas. La Tierra 15(4):29-33.

Powell, J. F. and D. G. Steele

1994 Diet and Health of Paleoindians: An Examination of Early Holocene Human Dental Remains. In Paleonutrition: The Diet and Health of Prehistoric Americans, edited by Kristen D. Sobolik, pp. 176-92. Occasional Paper No. 22. Center for Archaeological Investigations, Southern Illinois University, Carbondale.

Prewitt, E. R.

1981 Cultural Chronology in Central Texas. Bulletin of the Texas Archeological Society 52:65-89.

Quigg, J. M, and J. Peck

1995 The Rush Site (41TG346): A Stratified Late Prehistoric Locale in Tom Green County, Texas. Technical Report No. 816C. Mariah Associates, Inc., Austin, Texas.

Ricklis, R. A.

1995 The Ceramics of the Toyah Horizon and the Rockport Phase as Indicators of some Basic Sociocultural Patterns. Bulletin of Texas Archeological Society 66:195-203.

South Central Texas Regional Water Planning Group (SCTRWPG)

2006 Vegetational Areas. Electronic document, <http://www.watershedexperience.com/ish_vege_areas.html $>$, accessed July 2006.

Taylor, F. B.

1977 Soil Survey of Wilson County, Texas. U.S. Department of Agriculture Soil Conservation Service. The Soil Conservation Service, Washington, D.C.

Toomey, R. S., M. D. Blum, and S. Valastro, Jr.

1993 Late Quaternary Climates and Environments of the Edwards Plateau, Texas. Global and Planetary Change 7:299-320. 
Weir, F. A.

1976 The Central Texas Archaic. Unpublished Ph.D. dissertation. Department of Anthropology, Washington State University, Pullman.

Winkler, B. A.

1982 Wild Plant Foods of the Desert Gatherers of West Texas, New Mexico and Northern Mexico: Some Nutritional Values. Unpublished Master's thesis, Department of Anthropology, The University of Texas at Austin. 